\title{
Physicochemical properties and acceptability of three formulations containing fava bean, quinoa and corn flour extrudates
}

\author{
Propiedades fisicoquímicas y aceptabilidad de tres mezclas alimenticias a \\ base de harinas extruidas de haba, quinua y maíz.
}

Frank F. Velásquez-Barreto ${ }^{1}$; Edson E. Ramirez-Tixe²; Mariana D. Salazar-Irrazabal ${ }^{3}$; Elias Salazar-Silvestre ${ }^{4}$

\begin{tabular}{l}
\hline \multicolumn{2}{c}{ ARTICLE DATA } \\
\hline 1 Professor, M.Sc. Universidad Nacional Autónoma de \\
Chota, Chota-Cajamarca, Perú, frankervba@hotmail.com \\
2 M.Sc. Universidad Nacional Autónoma de Chota, Chota- \\
Cajamarca, Perú, erth-335@hotmail.com \\
3 Agroindustrial Engineer, Universidad Nacional de \\
Huancavelica, Acobamba-Huancavelica, Perú, \\
salimard_3101@hotmail.com \\
4 Agroindustrial Engineer, Universidad Nacional de \\
Huancavelica, Acobamba-Huancavelica, Perú, elias_el_ \\
unico@hotmail.com \\
\hline
\end{tabular}

Cite: Velásquez-Barreto, F.; Ramirez-Tixe, E.; SalazarIrrazabal, M.; Salazar-Silvestre, E. (2020). Physicochemical properties and acceptability of three formulations containing fava bean, quinoa, and corn flour extrudates. Revista de Ciencias Agrícolas. 37 (2): 40-48.

doi: https://doi.org/10.22267/rcia.203702.136

Received: August 32019.

Accepted: Decembre 122020.

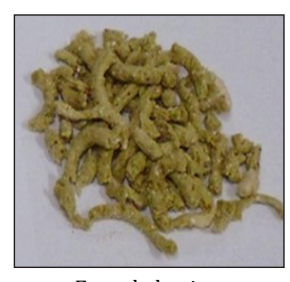

Extruded quinoa

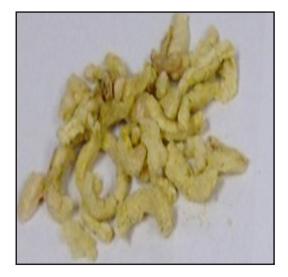

Extruded bean

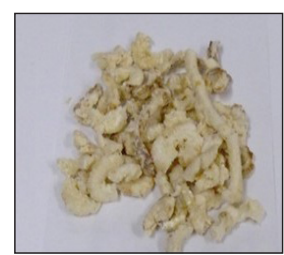

Extruded corn

\section{ABSTRACT}

Andean grains, widely distributed in the high areas of the Andean Highlands, can help to reduce malnutrition owing to their high content of protein and balance of essential amino acids. Recently, their consumption has changed as they are increasingly used for instant food mixtures. However, a better design and formulation are necessary to maintain Andean grains' nutritional value and characteristics. In this study, we evaluated the physicochemical properties and acceptability of three formulations containing extruded corn (Zea mays L.), fava bean (Vicia faba L.), and quinoa (Chenopodium quinoa Willd) flours. Grain samples were collected from Choclococha, Acobamba, Huancavelica, Peru, and extruded at $95^{\circ} \mathrm{C}$. Subsequently, three flour formulations were prepared. The formulation comprising $30 \%$ fava bean flour, $58 \%$ quinoa flour, and $12 \%$ corn flour consisted of $18.64 \%$ protein, $4.87 \%$ fat, $8.4 \%$ humidity, $2.99 \%$ ash, and $62.44 \%$ carbohydrates. This formulation with the highest quinoa flour content presented the highest acceptability in terms of color odor and flavor, and the highest protein content and digestibility (72.6\%) of all analyzed formulations. Thermal analysis and pasting testing indicated that the formulation with the highest acceptability did not contain native starch; moreover, the proteins in this formulation were denatured.

Keywords: Chenopodium; acceptability; Andean foods; instant foods; food formulations.

\section{RESUMEN}

Los granos andinos se encuentran ampliamente distribuidos en las zonas altas de la cordillera de los andes y pueden ayudar a enfrentar la desnutrición debido a su alto contenido de proteínas y a su balance de aminoácidos. Actualmente, el consumo de estos granos ha cambiado y se ha incrementado el uso en forma de mezclas alimenticias instantáneas. Sin embargo, un buen diseño y formulación son necesarios con el fin de mantener su valor nutricional y características sensoriales de los granos andinos. En este estudio, se evaluó las propiedades fisicoquímicas aceptabilidad de tres formulaciones alimenticias a base de 
harinas extruidas de maíz (Zea mays L.), haba (Vicia faba L.) y quinua (Chenopodium quinoa Willd). Los granos fueron recolectados del centro poblado de Choclococha, Acobamba, Huancavelica, Perú y fueron extruidas a $95^{\circ} \mathrm{C}$. Posteriormente, tres formulaciones fueron preparadas. La mejor formulación (30\% de harina de haba, $58 \%$ de harina de quinua y $12 \%$ de harina de maíz) presentó un contenido de proteínas de 18,64\%; grasa de 4,87\%; humedad de 8,4\%; cenizas de 2,99\%; carbohidratos de $62,44 \%$. Esta formulación con el más alto contenido en quinua mostró la mayor aceptabilidad en relación al color, olor y sabor, además un alto contenido de proteína y digestibilidad (72,6\%). El análisis térmico y la prueba pasting indicaron que la formulación con la mayor aceptabilidad no mostró la presencia de almidón nativo, así mismo, las proteínas de esta formulación fueron desnaturalizadas.

Palabras clave: Chenopodium; aceptabilidad; alimentos andinos; comidas instantáneas; formulaciones alimenticias.

\section{INTRODUCTION}

Several new nutritional trends have focused on products with health benefits such as Andean legumes and seeds (Mendoza-Jiménez et al., 2018). Recent studies have confirmed that Andean products are benefit for health because they contain soluble and insoluble fibers, resistant starch, proteins with bioactive properties, and phenolic compounds. (Delgado-Andrade et al., 2016). Quinoa (Chenopodium quinoa Willd), an Andean grain from Peru and Bolivia's Andean areas, is an ancestral food owing to its nutritional qualities (Tovar-Hernández et al., 2017).

Quinoa is consumed as raw grain, cooked, or processed into flour, bakery products, porridges, drinks, and fermented products. The quinoa's nutritional value depends on its protein contents, dietary fiber, minerals, and polyunsaturated fats. The protein content of dry quinoa varies between 13.8 and 16.5\%; however, it has been reported to be $15 \%$ on average (USDA, 2015). Moreover, quinoa is a valuable food source (Filho et al., 2017). Corn (Zea mays L.) supplements a significant amount of sulfur amino acids to the human diet (Estrada et al., 2015). Miranda et al. (2015) reported that the corn's protein content was 8.80\%; therefore, corn is an important food source. Corn is used for bakery products and represents an alternative for gluten-intolerant consumers. Therefore, it is necessary to expand the quantity and quality of corn-based products for consumers who adopt a gluten-free diet (Estévez and Araya, 2016).

Fava beans (Vicia faba L.) are a significant crop and income source in Peru's Andean areas. Fava beans are rich in protein, carbohydrates, dietary fiber, lecithin, minerals, and secondary metabolites (Etemadi et al., 2018). The protein content of fava beans ranges between 20 and 41\%, and the main proteins in fava beans are globulins (79\%), albumins (7\%), and glutelins (7\%) (Sathya and Devi, 2018). Fava beans have traces of several antinutritional factors, such as phytates, tannins, proanthocyanidins, sucrose, condensed tannins, protease inhibitors, and alkaloids. They are easily degraded via heat treatment (Coda et al., 2015).

Extrusion is a thermomechanical process that can alter the structure of starch, cause gelatinization and change the structure of native starch, because of the pressure and temperature used during the process, increasing starch digestibility. Moreover, other polymers, such as proteins, can change their structural architecture and become denatured during extrusion, facilitating their rapid degradation by digestive enzymes (Jiangping et al., 2017).

A large number of extruded products are processed and sold; as example there are pasta, breakfast cereals, breadcrumbs, cookies, croutons, baby food, snacks, confectionery, chewing gum, textured vegetable proteins, modified starch, pet food, dry 
soups, and dry drink mixes. Flours or grains, are subjected to extrusion to obtain products with particular sensory characteristics and functional properties; such as water absorption, water solubility, oil absorption indices, expansion indices, apparent density, and mass viscosity (Alama et al., 2015).

Numerous Andean grains (legumes and cereals) can help to reduce malnutrition in impoverished Andean areas of Peru. For this, the Andean grains' adequate industrial transformation with high nutritional value and optimization of instant flour formulations (food mixes) is required to improve Andean residents' nutritional status. Therefore, in this study, we evaluated the physicochemical characteristics and acceptability of three food formulations comprising extruded corn, fava bean, and quinoa flours.

\section{MATERIALS AND METHODS}

Characterization of raw materials. Fava beans, quinoa, and corn were collected from Choclococha, Acobamba, Huancavelica, Peru located at 3383 masl. The following methods were used to analyze the chemical composition of raw materials and food formulations: UNE-EN ISO 5983-2 for protein, UNE 64021-1970 for fat, UNE 640151971 for humidity, UNE 64019-1971 for ashes, and NMX-F-090-1978 for fiber; carbohydrates were determined by difference. The pepsin digestibility of the extruded mixtures was determined using the NMX-Y-085-SCFI-2006 standard method.

Extrusion. Extrusion was performed at the Technological Experimental Center of the National University of Callao. First, 500g of sample (fava beans and corn) were milled in a stainless-steel disc mill to an average size of $5-6 \mathrm{~mm}$. The quinoa grains were not ground owing to their small size. The milled samples were conditioned to a humidity of $9.32 \%$. Extrusion was performed in a single screw extruder at $95^{\circ} \mathrm{C}$, and a retention time of $15 \mathrm{~s}$ was used for all runs. Subsequently, the extruded samples were milled again using a hammer mill and were sieved using a Tyler $\mathrm{N}^{\circ} 35$ mesh, and stored on Kraft paper.

Formulation. The extruded formulations met the standard for infants recommended by the Food and Agriculture Organization/ World Health Organization (FAO/WHO) (2016). The following formulations were prepared: formulation $1\left(\mathrm{~F}_{1}\right)$ : $38 \%$ extruded fava bean flour, 50\% extruded quinoa flour, and $12 \%$ extruded corn flour; formulation $2\left(\mathrm{~F}_{2}\right): 36 \%$ extruded fava bean flour, $52 \%$ extruded quinoa flour, and 12\% extruded corn flour; and formulation $3\left(\mathrm{~F}_{3}\right)$ : 30\% extruded fava bean flour, $58 \%$ extruded quinoa flour, and $12 \%$ extruded corn flour.

Sensory analysis. Sensory analysis at the San Francisco de Asís Educational Institution, Acobamba was carried out based on the guidelines by the Peruvian Technical Standards (2008) (ISO 4121, 2008). For this, samples of the three extruded formulations were added to hot water, and equal amounts of sugar were added to each formulation. The color, taste, and odor acceptability of the formulations were evaluated by 30 panelists using a three-point hedonic scale (1 - I like it a lot, 2 - I like it, and 3 - I don't like it).

Thermal analysis. The Paredes-López et al. (1994) method was used to determine The flours' thermal properties and best extruded formulation $\left(\mathrm{F}_{3}\right)$. In brief, after $2 \mathrm{mg}$ of starch was weighed in an aluminum cell and $7 \mu \mathrm{L}$ of water was added to it, the cell was closed. Subsequently, the cell was placed in a differential scanning calorimeter (Q20, TA Instruments, New Castle, NJ, USA) and was heated in the temperature range of $30-120^{\circ} \mathrm{C}$ (heating rate of $10^{\circ} \mathrm{C} / \mathrm{min}$ ). The data and graphs were obtained using the calorimeter software. 
Pasting. The flours' pasting propeand best extruded formulation $\left(\mathrm{F}_{3}\right)$ were analyzed using a rheometer (Ar-1500ex, TA Instruments, New Castle, NJ, USA) equipped with a starch cell. Suspension of the flours and best extruded formulation $\left(\mathrm{F}_{3}\right)$ with concentrations of $12 \%$ $(\mathrm{w} / \mathrm{w})$ were prepared using the method of PérezGallardo et al. (2012). The prepared suspensions were stirred at $500 \mathrm{~s}^{-1}$. Next, the suspensions were warmed and maintained at $40^{\circ} \mathrm{C}$ for $600 \mathrm{~s}$ followed by heating to $95^{\circ} \mathrm{C}$ (heating rate of $7.5^{\circ} \mathrm{C} / \mathrm{min}$ ). Subsequently, the suspensions were maintained at $95^{\circ} \mathrm{C}$ for $600 \mathrm{~s}$ followed by cooling to $50^{\circ} \mathrm{C}$ (cooling rate of $7.5^{\circ} \mathrm{C} / \mathrm{min}$ ). Lastly, the suspensions were maintained at $50^{\circ} \mathrm{C}$ for $120 \mathrm{~s}$.

Statistical analysis. A completely randomized design with five repetitions was used to evaluate The extruded formulations' effect on their chemical composition parameters. Analysis of variance was performed to detect the differences between the formulations' average chemical composition parameters ( $\mathrm{p} \leq 0.05$ ). The least significant difference test was used to compare the chemical composition parameters of the grains and formulations. The acceptability of the extruded formulations was analyzed using the Friedman test, and statistical analysis of the data was performed using the SPSS 18.0 software.

\section{RESULTS Y DISCUSSION}

Chemical composition of raw materials. Table 1 summarize the chemical compositions of fava beans, corn, and quinoa. The protein content of fava beans (32.46\%) was higher than those of corn and quinoa and higher than that reported by Hernández-Bolívar et al. (2015), confirming that fava beans are an important source of protein (Kotue et al., 2018). Quinoa presented a high content of carbohydrates (74.26\%), it was higher than those of fava beans and corn; this value was slightly higher than those reported by CerónFernandez et al. (2016) (70.30\%) and Bergesse et al. (2015) (68 - 74\%).

The fat content of corn (5.98\%) was higher than fava beans and quinoa. This value was lower than that reported by Miranda et al. (2015) (6.58\%) but was in the range reported by $\mathrm{Ai}$ and Jane (2016) (3 - 6\%). The difference was attributed to the difference in the size of the corn germs (Ai and Jane, 2016). The ash contents of quinoa (5.49\%) and corn (4.96\%) were higher than fava beans. The ash content of quinoa was higher than reported by Arzapalo et al. (2015) for white quinoa (4.40\%) but was in the range reported by Bergesse et al. (2015) (2.22 - 9.80\%).

Table 1. Energy content and chemical composition of raw materials.

\begin{tabular}{lccc}
\hline Parameter & Fava beans & Corn & Quinoa \\
\hline Energy (kcal/100 g) & $369.49 \pm 0.94^{\mathrm{a}}$ & $369.98 \pm 0.23^{\mathrm{a}}$ & $355.06 \pm 0.42^{\mathrm{b}}$ \\
Humidity (\%) & $7.73 \pm 0.47^{\mathrm{b}}$ & $10.02 \pm 0.31^{\mathrm{a}}$ & $8.92 \pm 0.53^{\mathrm{c}}$ \\
Protein (\%) & $32.46 \pm 1.12^{\mathrm{b}}$ & $9.76 \pm 0.93^{\mathrm{a}}$ & $8.79 \pm 1.32^{\mathrm{c}}$ \\
Fat (\%) & $2.13 \pm 0.65^{\mathrm{b}}$ & $5.98 \pm 0.24^{\mathrm{a}}$ & $2.54 \pm 0.33^{\mathrm{c}}$ \\
Carbohydrates (\%) & $55.12 \pm 2.36^{\mathrm{b}}$ & $69.28 \pm 2.04^{\mathrm{a}}$ & $74.26 \pm 1.23^{\mathrm{c}}$ \\
Ash (\%) & $2.56 \pm 0.65^{\mathrm{b}}$ & $4.96 \pm 0.37 \underline{\underline{a}}$ & $5.49 \pm 0.74^{\mathrm{a}}$ \\
\hline
\end{tabular}

Data presented as means \pm standard deviations. Different letters in the same row indicate significant differences $(\mathrm{p}<0.05)$. 
Chemical compositions of extruded formulations. The chemical compositions of the extruded formulations showed the variability for the characteristics studied (Table 2). Formulation $\mathrm{F}_{2}$ presented the highest energy content, which agrre with the energy recommendations of the FAO/WHO (2016) of $60-70 \mathrm{kcal} / 100 \mathrm{~mL}$. However, no significant differences were observed in the formulations' energy contents. The protein content of formulation $\mathrm{F}_{2}$ was higher than formulations $\mathrm{F}_{1}$ and $\mathrm{F}_{3^{\prime}}$ and was attributed to its fava bean content being the highest of all formulations. Cereals, legumes, and grains are vegetal protein sources. Moreover, extrusion was reported to increase the protein content of legumecontaining formulations by 1-1.5\% (Patil et al., 2016).

The formulation of F1's carbohydrate content was the highest (62.69\%) of all analyzed formulations. The water content of the formulations was low (Table 2), guarantying the stability of extruded products during storage (Tovar-Hernández et al., 2017). The fat contents of the extruded formulations showed no significant differences. This behavior agreed with CerónFernandez et al. (2016). However, extrusion was reported to increase legume-based products' digestibility by $37-62 \%$, depending on the extrusion technique (Patil et al., 2016).

Sensory analysis of extrudates. Table 3 shows outcomes of the characteristics analyzed. The panelists reported significant differences in the taste and odor acceptability of the samples, and the sample with the highest odor and taste acceptability was formulation $\mathrm{F}_{3}$. No significant differences were observed in the color acceptability of the formulations. This was attributed to The formulations' quiona content". Jiangping (2017) mentioned that extrusion significantly affected the organoleptic characteristics of color and bouquet because of the high temperature used during the process. However, to maintain these characteristics is advisable to add colorant additives to formulations.

Table 2. Energy content, chemical composition, and digestibility of extruded formulations.

\begin{tabular}{lccc}
\hline \multirow{2}{*}{ Parameter } & $\mathbf{F}_{1}$ & $\mathbf{F}_{2}$ & $\mathbf{F}_{3}$ \\
\cline { 2 - 4 } & $366.74 \pm 3.40^{\mathrm{a}}$ & $369.88 \pm 2.80^{\mathrm{a}}$ & $368.15 \pm 3.90^{\mathrm{a}}$ \\
\hline Energy (kcal/100 g) & $18.24 \pm 0.03^{\mathrm{a}}$ & $19.17 \pm 0.04^{\mathrm{b}}$ & $18.64 \pm 0.08^{\mathrm{c}}$ \\
Proteins (\%) & $4.78 \pm 0.21^{\mathrm{a}}$ & $4.88 \pm 0.19^{\mathrm{a}}$ & $4.87 \pm 0.32^{\mathrm{a}}$ \\
Fat (\%) & $7.80 \pm 0.04^{\mathrm{a}}$ & $8.00 \pm 0.13^{\mathrm{b}}$ & $8.40 \pm 0.05^{\mathrm{c}}$ \\
Humidity (\%) & $3.15 \pm 0.01^{\mathrm{a}}$ & $3.11 \pm 0.06^{\mathrm{a}}$ & $2.99 \pm 0.01^{\mathrm{b}}$ \\
Ash (\%) & $3.34 \pm 0.01^{\mathrm{a}}$ & $2.52 \pm 0.02^{\mathrm{b}}$ & $2.66 \pm 0.03^{\mathrm{c}}$ \\
Fiber (\%) & $62.69 \pm 0.08^{\mathrm{b}}$ & $62.32 \pm 0.23^{\mathrm{a}}$ & $62.44 \pm 0.16^{\mathrm{a}}$ \\
Carbohydrates (\%) & $72.80 \pm 1.28^{\mathrm{a}}$ & $71.9 \pm 0.98^{\mathrm{a}}$ & $72.60 \pm 1.08^{\mathrm{a}}$ \\
\hline Digestibility (\%) & &
\end{tabular}

$\mathrm{F}_{1}: 38 \%$ extruded fava bean flour, $50 \%$ extruded quinoa flour, and $12 \%$ extruded corn flour; $\mathrm{F}_{2}: 36 \%$ extruded fava bean flour, $52 \%$ extruded quinoa flour, and $12 \%$ extruded corn flour; $\mathrm{F}_{3}: 30 \%$ extruded fava bean flour, $50 \%$ extruded quinoa flour, and $12 \%$ extruded corn flour.

Data presented as means \pm standard deviations. Different letter in the same row indicate significant differences $(p<0.05)$. 
Table 3. Sensory acceptability of the extruded formulations.

\begin{tabular}{cccc}
\hline Formulation & Color & Taste & Odor \\
\hline $\mathrm{F}_{1}$ & $1.90 \pm 0.71^{\mathrm{a}}$ & $2.70 \pm 0.46^{\mathrm{c}}$ & $2.43 \pm 0.57^{\mathrm{b}}$ \\
$\mathrm{F}_{2}$ & $1.93 \pm 0.69^{\mathrm{a}}$ & $2.53 \pm 0.68^{\mathrm{bc}}$ & $2.33 \pm 0.71^{\mathrm{b}}$ \\
$\mathrm{F}_{3}$ & $1.47 \pm 0.51^{\mathrm{a}}$ & $1.73 \pm 0.52^{\mathrm{a}}$ & $1.63 \pm 0.61^{\mathrm{a}}$ \\
\hline
\end{tabular}

Data presented as means \pm standard deviations. Different letters in the same column indicate significant differences $(\mathrm{p}<0.05)$.

The extruded formulation with the highest odor and taste acceptability was $\mathrm{F}_{3}$. It was attributed to the quinoa content because Cerón-Fernandez et al. (2016) reported that quinoa grains contributed to the sweetness of extruded formulations. The taste acceptability of the formulations was attributed to the extrusion process, affecting the characteristics of fava beans, quinoa, and corn; improving the texture and reducing the quinoa and fava beans' bitter taste (Patil et al., 2016). Formulation $\mathrm{F}_{3}$ presented a better sweet taste in the final product. The panelists favored formulation $\mathrm{F}_{3}$ and indicated that this sample presented a pleasant color and sweet taste; Cerón-Fernandez et al. (2016) reported similar results. The extruded formulations' quiona content did not affect the color or appearance of the formulations.

Thermal properties. The thermograms of the non-extruded fava beans, quinoa, corn flours and extruded formulation with the highest acceptability $\left(\mathrm{F}_{3}\right)$ are in Figure 1. The gelatinization temperatures of the non-extruded flours were higher than the extruded formulation. These differences were attributed to the non-extruded flours containing native starch (Velásquez-Barreto et al., 2019). This did not occur for the extruded formulation because the starch had already been gelatinized during extrusion. Ye et al. (2018) mentioned that, starch granules gelatinized and proteins were denatured during extrusion, improving their digestibility, texture, and organoleptic properties.
Moreover, the drinks prepared for sensory analysis presented a good dispersion due to starch gelatinization. Conversely, the extruded products presented high or complete gelatinization of native starch, indicating that extrusion was efficient, due to the absence of a gelatinization temperature from the thermogram of formulation $\mathrm{F}_{3}$ (Figure 1).

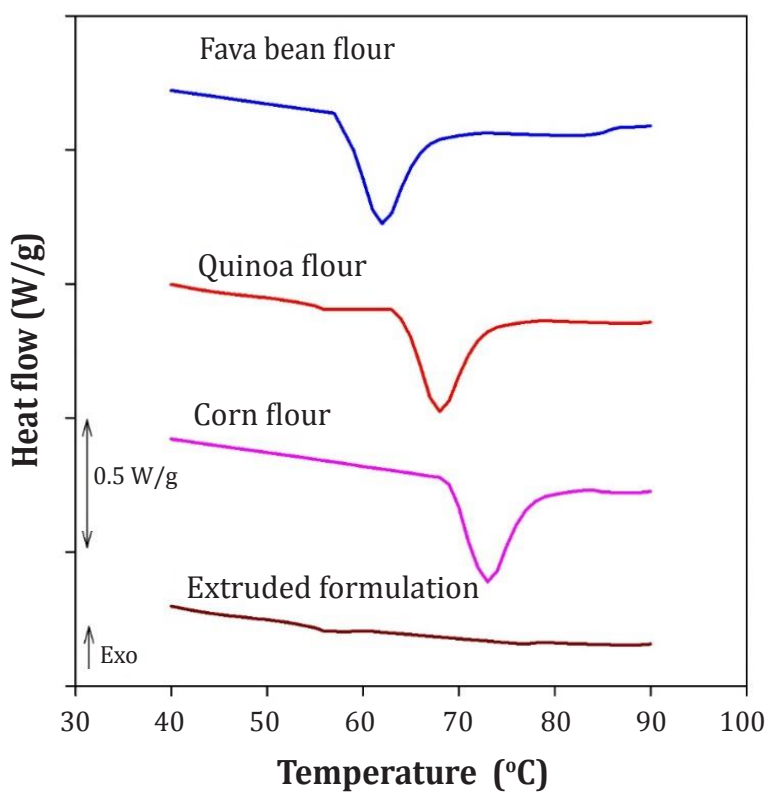

Figure 1. Thermograms of non-extruded fava bean, quinoa, and corn flours, and extruded formulation $\left(\mathrm{F}_{3}\right)$.

Pasting. Pasta obtained from non-extruded fava beans, quinoa, and corn presented similar comportments (Figure 2), and differed from the extruded formulation with the highest acceptability $\left(\mathrm{F}_{3}\right)$. This behavior was attributed to the native starch swelling upon heating non- 
extruded flours owing to heating and mechanical agitation (Velásquez-Barreto et al., 2019). But it was not observed for the $\mathrm{F}_{3}$ formulation because the starch had already been gelatinized and lost its integrity. These results were consistent with the thermograms. Quinoa flour presented the highest peak viscosity followed by fava bean and corn flours. The gelatinization temperatures of the nonextruded corn, quinoa, and fava bean flours were $72.1,64.5$ and $68.7^{\circ} \mathrm{C}$, respectively. These results were similar to those reported by BustillosRodríguez et al. (2018), ranging between 70.6 and $72.2^{\circ} \mathrm{C}$. Moreover, Arzapalo et al. (2015) reported that the gelatinization temperature of quinoa starch was $66^{\circ} \mathrm{C}$, and Wani et al. (2016) indicated that fava beans' starch gelatinization temperature ranged between 66.6 and $70.59^{\circ} \mathrm{C}$. Formulation $\mathrm{F}_{3}$ did not present a pasting temperature or peak viscosity, indicating that the native starch in this formulation was highly or completely gelatinized and confirmed that extrusion was efficient. These results were in agreement with the thermal properties of the analyzed flour samples.

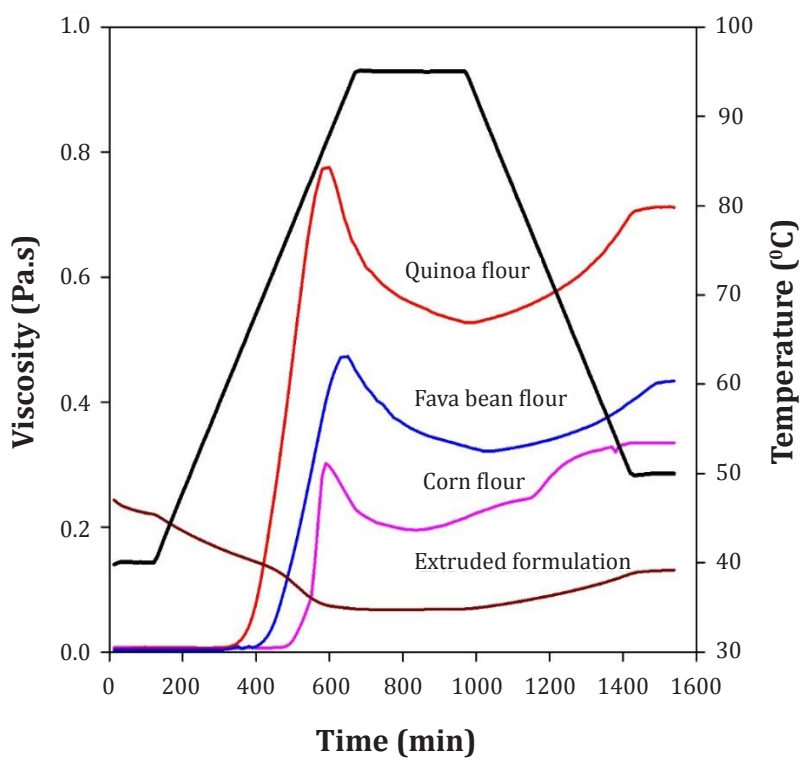

Figure 2. Behavior of non-extruded fava bean, quinoa, and corn flours and extruded formulation $\left(\mathrm{F}_{3}\right)$

\section{CONCLUSIONS}

The chemical composition and energy of fava beans, corn, and quinoa in this study agreed with the data reported in the literature. Extruded formulations of corn, fava beans, and quinoa presented the following chemical compositions: protein (18.24 - 19.17\%), fat (4.78 - 4.88\%), humidity (7.8 - 8.4\%), ash (2.99 $3.15 \%)$, fiber (2.52 - 3.34\%), carbohydrates (62.32 $-62,69 \%)$ and digestibility (71.9 - $72.8 \%$ ).

The extruded formulation with the highest acceptability consisted of fava bean (30\%), quinoa (58\%) and corn (12\%) flours; the odor, taste, and, color parameters of this formulation were $1.63,1.73$, and 1.47, respectively. The extruded formulation's thermal and pasting properties with the highest acceptability indicated that the entire amount of native starch present in the flours was gelatinized during extrusion.

This extruded formulation could be used as instant breakfast food for children and adults owing to its chemical composition and acceptability. Future studies should focus on the in vivo digestibility of these formulations and determining their amino acid balance to obtaining optimal formulations of extruded corn, fava bean, and quinoa flours.

Acknowledgements. The authors would like to thank the National University of Huancavelica for financing a part of this study.

Conflict of interest: The authors declare that there is no conflict of interest.

\section{BIBLIOGRAPHIC REFERENCES}

Ai, Y.; Jane, J. (2016), Macronutrients in Corn and Human Nutrition. Revisiones integrales en ciencia y seguridad alimentaria. 15: 581-598. doi: https:// doi.org/10.1080/10408398.2013.779568 
Alama, M.; Kaurb, J.; Khairab, H.; Guptab, K. (2015). Extrusion and Extruded Products: Changes in Quality Attributes as Affected by Extrusion Process Parameters: A Review. Critical Reviews in Food Science and Nutrition. 56(3): 445-75. doi: https:// doi.org/10.1080/10408398.2013.779568

Arzapalo, D.; Huamán, K.; Quispe, M.; Espinoza, C. (2015). Extracción y caracterización del almidón de tres variedades de quinua (Chenopodium quinoa Willd) negra collana, pasankalla roja y blanca Junín. Rev. Soc. Quím. Perú. 81 (1): 44-54.

Bergesse, A.; Boiocchi, P.; Calandri, E.; Cervilla, N.; Gianna, V.; Guzmán, C.; Miranda, V.; Patricia, P.; Montoya, P.; Mufari, J. (2015). Aprovechamiento integral del grano de quinua: Aspectos Tecnológicos, Fisicoquímicos, Nutricionales y Sensoriales. $1^{\circ} \mathrm{ed}$. Córdoba: Edgardo Luis Calandri. 262p.

Bustillos-Rodríguez, J.; Tirado-Gallegos, J.; OrdóñezGarcía, M.;Zamudio-Flores, P.; Ornelas-Paz,J.; AcostaMuñiz, C.; Gallegos-Morales, G.; Páramo-Calderón, D.; Rios-Velasco, C. (2018). Physicochemical, thermal and rheological properties of three native corn starches. Food Science and Technolpgy. 39(1): 149-157. doi: https://doi.org/10.1590/fst.28117

Cerón-Fernandez, C.; Guerra-Morcillo, L.; LegardaQuintero, J.; Enríquez-Collazos, M.; PismagPortilla, Y. (2016). Efecto de la extrusión sobre las características físico-químicas de harina de quinua (Chenopodium quinoa Willd). Biotecnología en el Sector Agropecuario y Agroindustrial. 14 (2): 92-99. doi: http://dx.doi.org/10.18684/BSAA(14)92-99

Coda, R.; Melama, L.; Rizzello, C.; Curiel, J.; Sibakov, J.; Holopainen, U.; Pulkkinen, M.; Sozer, N. (2015). Effect of air classification and fermentation by Lactobacillus plantarum VTT E-133328 on faba bean (Vicia faba L.) flour nutritional properties. International Journal of Food Microbiology. 193: 34-42. doi: https://doi.org/10.1016/j. ijfoodmicro.2014.10.012

Delgado-Andrade, C.; Olías, R.; Jiménez-López, J.; Clemente A. (2016). Aspectos de las legumbres nutricionales y beneficiosos para la salud humana. Arbor. 192(779): a313. doi: http://dx.doi. org/10.3989/arbor.2016.779n3003
Estévez, V.; Araya, M. (2016). La dieta sin gluten y los alimentos libres de gluten. Chile de Nutrición. 43 (4): 420-433. doi: http://dx.doi.org/10.4067/S071775182016000400014

Estrada, Y.; Martínez, A.; Rafael, C.; Armando, F. (2015). Characterization of Extruded Blends of Corn and Beans (Phaseolus Vulgaris) Cultivars: Peruano and Black-Querétaro under Different Extrusion Conditions. International Journal of Food Properties, 18(2): 638-2651. doi: https://doi.org/10.1080/10 942912.2014 .999862

Etemadi, F.; Hashemi, M.; Autio, W.R.; Mangan, F.X.; Zandvakili, 0. (2018). Yield and Accumulation Trend of Biomass and L-DOPA in Different Parts of Eight Faba Bean Cultivars. Crop Sci. 58(1): 2020-2028. doi: https://doi.org/10.2135/cropsci2018.03.0172

Filho, A.; Pirozi, M.; Borges J.; Pinheiro, H.; Chaves, J.; Coimbra, J. (2017). Quinoa: nutritional, functional and antinutritional aspects. Crit Rev Food Sci Nutr. 57(8): 1618-1630. doi: https://doi.org/10.1080/10 408398.2014.1001811

FAO - Food and Agriculture Organization / WHO World Health Organization. (2016). Comisión del Codex Alimentarius: Revisión de la norma para preparados complementarios (codex stan 1561987). Recovered from https://cutt.ly/ihiNbGu

Hernández-Bolívar, G.; Matute-Sapuysky, I.; MorenoHernández, D.; Araujo-González, M.; RamírezAlfonzo, L.; Linares-Padrón, H.; Mercedes-Arveláez, Y.; Loaiza-González, J.; Monsalve, J.; Judith, M. (2015). Valor nutricional de la harina de haba (Vicia faba L.) en la alimentación de alevines de Coporo (Prochilodus mariae). Revista Científica, FCV-LUZ. 25(3): 255 - 259.

Jiangping, Y.; Xiuting, H.; Shunjing, L.; Wei, L.; Jun, C.; Chengmei, L.; Zhiru, Z. (2017). Properties of starch after extrusion: A review. Starch-Stärke. 70(1112): 1700110. doi: https://doi.org/10.1002/ star.201700110

Kotue, T.C.; Marlyne, J.M.; Wirba, L.Y. (2018). Nutritional properties and nutrients chemical analysis of common beans seed. MOJ Biol Med. 3(3):41-47. doi: 10.15406/mojbm.2018.03.00074 
Mendoza-Jiménez, Y.; Eusebio-Moreno, J.; ÁlvarezGarcía, R.; Abreu-Corona, A.; Vergas-Hernández, G.; Téllez-Jurado, A.; Tovar-Jiménez, X. (2018). Actividad antioxidante de los hidrolizados proteicos del frijol común (Phaseolus vulgaris) cv negro primavera-28 y flor de durazno. Rev. Ciencias Biológicas y de la Salud. 20(2): 25-30.

Miranda, S.; Esquivel, J.; Ruiz J.; Rivers, E. (2015). Análisis proximal de granos de arroz, frijol, maíz y café comercializados en el mercado Roberto Huembes de Managua. Rev. Universidad y Ciencia. 8(13): 41-46.

Paredes-López, 0; Bello-Pérez, L., López, G. (1994). Amylopectin-structural, gelatinization and retrogradation studies. Rev. Food Chemistry. 50: 411-417.

Patil, S.; Brennan, M.; Mason, S.; Brennan, C. (2016). The Effects of Fortification of Legumes and Extrusion on the Protein Digestibility of Wheat Based Snack. Foods. 5. (26):1-8. doi: https://doi.org/10.3390/ foods 5020026

Pérez-Gallardo, A.; Bello-Pérez, L; García-Almendárez, B.; Montejano-Gaitán, G.; Barbosa-Cánovas, G.; Regalado, C. (2012). Effect of structural characteristics of modified waxy corn starches on rheological properties, film-forming solutions, and on water vapor permeability, solubility, and opacity of films. Starch/Stärke. 64: 27-36. doi: https://doi. org/10.1002/star.201100042

Peruvian Technical Standards. (2008). Análisis sensorial. Directrices para la utilización de escalas de respuestas cuantitativas (ISO 4121).

Sathya, D.; Devi, V. (2018). Nutritional and Biological properties of Vicia faba L.: A perspective review. Rev. International Food Research Journal. 25(4): 1332-1340.

Tovar-Hernández, C.; Perafán-Gil, E.; Enríquez-Collazos, M.; Pismag-Portilla, Y.; Ceron- Fernandez, L. (2017). Evaluación del efecto del proceso de extrusión en harina de quinua (Chenopodium quinoa Willd) normal y germinada. Biotecnología en el Sector Agropecuario y Agroindustrial. 15(2): 30-38. doi: http://dx.doi.org/10.18684/BSAA(15)30-38

USDA - United States Department of Agriculture. (2015). National Nutrient Database for Standard
Reference Release, 28 (Basic Reports). Recovered from https://cutt.ly/Dhi1txG

Velásquez-Barreto, F; Bello-Pérez, L.; Yee-Madeira, H.; Velezmoro, C. (2019). Esterification and Characterization of Starch From Andean Tubers. Starch-Starke. 71(1-2): 1-8. doi: https://doi. org/10.1002/star.201800101

Wani, I.; Sogi, D.; Hamdani, A.; Gani, A.; Bha, N.; Shah, A. (2016). Isolation, composition, and physicochemical properties of starch from legumes: A review. Starch-Starke. 68 (9-10): 834-845. doi: https://doi. org/10.1002/star.201600007

Ye, J.; Hu, X.; Luo, S.; Liu, W.; Chen, J.; Zeng, Z.; Liu, C. (2018). Properties of starch after extrusion: A review. Starch-Starke. 70 (1700110): 1-8. doi: https://doi.org/10.1002/star.201700110. 